\title{
Globalization and Citizenship Education in Hong Kong and Taiwan
}

\author{
WING-WAH LAW
}

In recent decades, educational and curricular reforms worldwide have been designed with the goal of preparing citizens for the challenges of globalization. Globalization has been thought to require the broadening of children's occupational perspectives beyond conventional geopolitical borders and cultures. And this requirement has led to doubts about the importance of borders and nation-states and to calls for a multileveled citizenship polity. ${ }^{1}$ Notwithstanding the demands to create global citizens, in Hong Kong and in Taiwan, as will be shown in this essay, school curricula have responded to contemporary sociopolitical changes primarily in relation to the People's Republic of China (PRC). Recent reforms in both Hong Kong and Taiwan have emphasized generic and transnational skills, such as English proficiency and information technology, and developed tripartite frameworks for citizenship education at local, national, and global levels. At the same time, the schools of both polities have included local languages, histories, and identities into their curricula, in each case expressing a different relation with the PRC when refocusing their national identities. In sum, the schools of both societies have paid more attention to local and national than to global concerns. In this sense, the reconfiguration of citizenship and citizenship education in Hong Kong and Taiwan are useful counterexamples to the predictions of transnational convergence offered by some globalization theorists.

\section{Globalization, Nation-State, and Citizenship Education}

Educational theorists have challenged an exclusive focus of citizenship and citizenship education on borders, nation, and nationality. Notwithstanding many important single-state and comparative studies of citizenship education, there is an identity crisis of citizenship and citizenship education in

\footnotetext{
${ }^{1}$ Richard Falk, "The Making of Global Citizenship," in The Condition of Citizenship, ed. Bart van Steenbergen (London: Sage, 1994), pp. 127-40; Julian Nida-Ruemelin, "Redefining Citizenship," Taipei Times (January 30, 2002), p. 9; T. K. Oommen, "Introduction: Conceptualizing the Linkage between Citizenship and National Identity," in his Citizenship and National Identity: From Colonialism to Globalism (New Delhi: Sage, 1997), pp. 13-51. See also Gerard Delanty, Citizenship in a Global Age: Society, Culture, Politics (Buckingham: Open University Press, 2000).

Comparative Education Review, vol. 48, no. 3.

(C) 2004 by the Comparative and International Education Society. All rights reserved. 0010-4086/2004/4803-0000\$05.00
} 
the face of this fundamental challenge. ${ }^{2}$ Globalization has been perceived as causing inevitable changes across nations and a universal tendency for convergence. However, there is no commonly accepted definition or model of globalization, and some theorists question whether globalization is a myth or reality, a prescription or a description. ${ }^{3}$ Others argue for the convergent effects of globalization on the economic, political, and cultural dimensions of human activities. Scholars such as Fukuyama, Ohmae, and Tomlinson predict the erosion of borders and state sovereignty, and a spread of liberal democratic systems and culture. This could accompany the emergence of a single consumer culture across societies and the dissolution of local cultures and patterns of life. ${ }^{4}$ Against these arguments for convergence, others have noted divergent national responses (including resistance) to economic, political, and cultural globalization as well as the importance of the state in protecting global capital and in preserving national institutions and cultural specifics. ${ }^{5}$ Between these two possibilities, others have argued for more accommodative frameworks. ${ }^{6}$ These accommodations would recognize the mutual interactions between global and local forces, and the coexistence of homogeneity and heterogeneity arising from such interactions in economic, political, and cultural arenas.

Education researchers such as Carnoy and Rhoten, as well as Green, have applied these issues specifically to studies of citizenship and citizenship education. ${ }^{7}$ In reference to the nation-state, citizenship has been understood

\footnotetext{
${ }^{2}$ For example, Carole Hahn, Becoming Political: Comparative Perspectives on Citizenship Education (Albany, N.Y.: SUNY Press, 1998); Kerry J. Kennedy, "Citizenship Education in Review: Past Perspectives and Future Needs," in his Citizenship Education and the Modern State (London: Falmer, 1997), pp. 1-5.

${ }^{3}$ Ian Clark, Globalization and International Relations Theory (Oxford: Oxford University Press, 1999); Paul Hirst and Grahame Thompson, Globalization in Question: The International Economy and the Possibilities of Governance (Cambridge, Mass.: Polity Press, 1996); David Held, Anthony McGrew, David Goldblatt, and Jonathan Perraton, Global Transformations: Politics, Economics and Culture (Cambridge: Polity Press, 1998).

${ }^{4}$ Francis Fukuyama, The End of History and the Last Man (New York: Free Press, 1992); Kenichi Ohmae, The Borderless World: Power and Strategy in the Interlinked Economy (New York: HarperPerennial, 1990); John Tomlinson, Globalization and Culture (Cambridge: Polity Press, 1999); Malcolm Waters, Globalisation (London: Routledge, 1995).

${ }^{5}$ Stephen Krasner, "Globalization and Sovereignty," pp. 34-52; Vivien A. Schmidt, "Convergent Pressures, Divergent Responses: France, Great Britain, and Germany between Globalization and Europeanization," pp. 172-92, both in States and Sovereignty in the Global Economy, ed. David A. Smith, Dorothy J. Solinger, and Steven C. Topik (London: Routledge, 1999); Waters. On the divergence of nations' paths with respect to "democratization," see R. W. Compton, East Asian Democratization: Impact of Globalization, Culture, and Economy (Westport, Conn.: Praeger, 2000); United Nations Development Programme (UNDP), Human Development Report 2002: Deepening Democracy in a Fragmented World (New York: UNDP, 2002).

${ }^{6}$ Thomas L. Friedman, The Lexus and the Olive Tree: Understanding Globalization (New York: Farrar, Straus \& Giroux, 2000); Roland Robertson, "Glocalization: Time-Space and Homogeneity-Heterogeneity," in Global Modernities, ed. Mike Featherstone, Scott Lash, and Roland Robertson (London: Sage, 1995), pp. 25-44.

${ }^{7}$ Martin Carnoy and Diana Rhoten, "What Does Globalization Mean for Educational Change? A Comparative Approach," Comparative Education Review 46 (February 2002): 1-9; Andy Green, "Education and Globalization in Europe and East Asia: Convergent and Divergent Trends," Journal of Education Policy 14 (1999): 55-71.
} 
as a basis for community, a source of personal identity, and a model of social organization. ${ }^{8}$ With these understandings, the natural focus of citizenship education has been on the nation-state's political sovereignty and legitimacy, and on citizens' rights and responsibilities. Globalization has challenged the notion of citizenship and citizenship education in two major respects. First, part of the nation-state's power is transferred downward to nongovernmental institutions (such as private companies) and upward to regional institutions (such as the European Union) or to transnational or supranational agencies (such as the World Trade Organization). ${ }^{9}$ Second, globalization creates new economic, social, and cultural arenas that frequently transcend national borders to reach regional or global levels. ${ }^{10}$ Consequently, nation-states no longer serve as the exclusive source of legitimacy for political activity, nor do they dominate the discourse of citizenship, which tends increasingly to be stripped of national characteristics.

Several theoretical responses to globalization have been suggested for the role of citizenship education in this changed environment. One response questions the very need for a state role. For example, Oommen understands citizenship primarily in terms of individual and group identities. Similarly, with respect to the new European citizen, Nida-Ruemelin argues against the need for traditional traits of citizenship, such as a shared common life or historical experiences, and emphasizes individuals who interact as citizens with specific goals and interests. A second response advocates a wider concept of citizenship to include subnational, regional, and global levels. For example, Turner argues that the location of citizenship should not be limited to the nation-state but expanded to include world ecology; global, social, and economic relations; and world religions. ${ }^{11}$ Similarly, Preston argues that individuals have multiple layers of identities, as members of the community, national polity, and various regional and global institutions. Their political-cultural identities are "multiple and situational." Delanty suggests that a new "civic cosmopolitanism" could reconfigure citizenship in a multilevel polity, which comprises three major tiers of governance-subnational, national, and transnational. The forces of globalization influence the polity by stimulating both the internal transformation of public spheres at national and subnational

\footnotetext{
${ }^{8}$ Craig Calhoun, "Nationalism, Political Community and the Representation of Society," European Journal of Social Theory 2 (1999): 217-31; Rob Gilbert, "Issues for Citizenship in a Postmodern World," in Kennedy, ed., pp. 65-81; Victor Roudometof, "Nationalism, Globalization, Eastern Orthodoxy: 'Unthinking' the 'Clash of Civilizations' in Southeastern Europe," European Journal of Social Theory 2 (1999): 233-47.

${ }^{9}$ Delanty, Citizenship in a Global Age.

${ }^{10}$ Anthony Giddens, "Runaway Word: The Reith Lectures Revisited, Globalization" (London School of Economics and Political Science, 1999), available at http:/ /www.lse.ac.uk/Giddens/pdf/10-Nov-99 .PDF; P. W. Preston, Political/Cultural Identity: Citizens and Nations in a Global Era (London: Sage, 1997).

${ }^{11}$ Bryan S. Turner, "Contemporary Problems in the Theory of Citizenship," in his Citizenship and Social Theory (London: Sage, 1993), pp. 1-18, and "Cosmopolitan Virtue," European Journal of Social Theory 4 (2001): 131-52.
} 
levels and the growth of transnational communication and governance. ${ }^{12}$ The third response comes from those who argue that the forces of globalization actually intensify the nation-state's importance in the construction of citizenship. Nation-states remain key actors on the world stage. They remain the sites of governance, social cohesion, and struggles for power and resources among different social groups or classes. ${ }^{13}$ Even though Delanty advocates civic cosmopolitanism, he admits that national governments are essential to protecting political, civil, social, and cultural rights. ${ }^{14}$ The forces of globalization may become intertwined with those of localization and heterogeneity by articulating local and national identities, leading to a greater identification with national and local cultures. ${ }^{15}$ Touraine contends that differences between peoples are exacerbated as they struggle to maintain their identities against the encroaching forces of globalization. ${ }^{16}$

These three theoretical responses to globalization also suggest different practical responses from those concerned with citizenship education. On the one hand, in no country have school systems relinquished their particular citizenship education in favor of a global model. On the other hand, there are clear indications that promoting global citizenship has stimulated curricular reforms in preparation for globalization's economic, political, and cultural challenges. In addition to foreign languages and information technology, many transnational agencies and governments promote the teaching of "learning to live together" through understanding and respect for other peoples and cultures, and through renewed concerns for peace, human rights, and democracy. ${ }^{17}$ There are also clear indications of education serving a multileveled citizenship, as well as a trend toward emphasizing local and national (vs. global) citizenships. While UNESCO urges countries to adapt their curricula to globalization, it also supports the maintenance of national and social cohesion by encouraging a search for specific roots and respect for national differences. ${ }^{18}$

Countries are increasingly caught in the tension between global and local identities. In the school curricula of the United States, Australia, and United Kingdom, local and national citizenship education is promoted to prepare

\footnotetext{
${ }^{12}$ Gerard Delanty, "Cosmopolitanism and Violence," European Journal of Social Theory 4 (2001): 41-52; see also Patricia Kubow, David Grossman, and Akira Ninomiya, "Multidimensional Citizenship," in Citizenship for the Twenty-First Century: An International Perspective on Education, ed. John J. Cogan and Ray Derricott (London: Kogan-Page, 2000), pp. 115-34.

${ }^{13}$ Simon Marginson, "After Globalization: Emerging Politics of Education," Journal of Education Policy 14 (1999): 19-31.

${ }^{14}$ Delanty, Citizenship in a Global Age (n. 1 above).

${ }^{15}$ Fay Chung, "Universal Values and Particularistic Values in World Educational Systems," International Journal of Educational Reform 8 (1999): 108-12.

${ }^{16}$ Alain Touraine, Can We Live Together? (Stanford, Calif.: Stanford University Press, 2000).

${ }^{17}$ Noel F. McGinn, "The Impact of Globalization on National Education Systems," Prospects 27 (1997): 41-54; UNESCO, World Education Report (Paris: UNESCO, 2000).

${ }^{18}$ UNESCO, Learning: The Treasure Within (Paris: UNESCO, 1996).
} 
students for global economic competition. Since the publication of A Nation at Risk in 1983, American educators have advocated instruction in civics and government to enhance students' civic attitudes and participation. ${ }^{19}$ In 1997 Australia introduced a 4-year national citizenship education program to help students develop and reinforce their Australian civic identity. ${ }^{20}$ Since 2002, British secondary students have been required to learn British political and legal systems, and encouraged to appreciate the United Kingdom's national, local, religious, and ethnic identities and its relations with the European Union, the Commonwealth, and the rest of the world. ${ }^{21}$ Japan and Singapore are incorporating globalization into their national goals and, in their corresponding redefinition of labor force needs, are encouraging their students to go global and to develop a sense of belonging to the homeland. ${ }^{22}$

In common with these examples, Hong Kong and Taiwan face the challenges of economic, political, and cultural globalization. They must promote citizenship education in a tripartite (local, national, and global) polity. Like other countries, they seek to develop both global and national/local identities. However, Hong Kong and Taiwan differ from these countries due to their unique relationship with the PRC. The reconfiguration of citizenship education in Hong Kong and Taiwan responds to the PRC more than to global opportunities. Education also responds to a change of national identity and sovereignty as well as to increased democracy. The result involves complex tensions between local, national, and global languages and identities. The modification of citizenship curricula in Hong Kong and in Taiwan is a sociopolitical exercise of reselection and repoliticization. The curricular reforms widen coverage beyond Western countries, and they also emphasize local history, language, culture, and identity. This modification shifts the focus of national identity by adjusting civic relations with the PRC.

\section{Broadening the Global Component of Citizenship Education}

Hong Kong and Taiwan are expanding the international component of their citizenship curricula to include global citizenship. Formerly, both governments tolerated students' exposure to the political systems and cultures of selected countries, but only within their official frameworks. In Hong Kong,

\footnotetext{
${ }^{19}$ Andrew R. Weiss, Anthony D. Lutkus, Wendy S. Grigg, and Richard G. Nierna, The Next Generation of Citizens: NAEP Civics Assessment-1988 and 1998 (Washington, D.C.: U.S. Department of Education, 2001).

${ }^{20}$ Curriculum Corporation, Introducing Discovering Democracy (Carlton, Victoria: Curriculum Corporation, 1997).

${ }^{21}$ Department for Education and Employment of the United Kingdom, The National Curriculum for England: Citizenship (London: Department for Education and Employment, and Qualifications and Curriculum Authority, 1999). See also Schmidt (n. 5 above).

${ }^{22}$ Ministry of Education, Culture, Sports, Science and Technology, "Japanese Government Policies in Education, Science, Sports and Culture 2000: Toward a Culturally-Oriented Nation" (Government of Singapore, 2000), at http://wwwwp.mext.go.jp/hakusyo/book/hpae200001/hpae200001_2_072.html; Government of Singapore, Singapore 21: Together We Make the Difference (Singapore: 2001).
} 
the curricular guides for primary and secondary schools did not emphasize the global dimension of citizenship education in their lists of goals and contents. ${ }^{23}$ The study of history was intended to broaden students' understanding of developments in the rest of the world within the colonial framework. History curricula covered the political systems and cultures of mainly Western countries during the nineteenth and twentieth centuries. In their treatment of historical events that related to the United Kingdom, Hong Kong's English-media history textbooks used terms or offered interpretations that differed from those presented in the Chinese history curricula. For example, the conflict between China and Britain in the 1840s was called the "Sino-British War" in English-media history textbooks but was termed the "Opium War" in Chinese texts.

Taiwan's government, under the leadership of Kuomintang (KMT), transmitted its worldview to students through the school curriculum. The curriculum standards of elementary and junior secondary schools briefly mentioned love for the world as a quality of good citizens' cultural exchanges and manners on international occasions. ${ }^{24}$ However, explicit messages of the leadership's bipolar ideological worldview were quite common in textbooks, particularly those for compulsory political subjects. For example, senior secondary school civics compared the ethics and political systems of Western countries, including the United Kingdom and the United States, with those of Taiwan. ${ }^{25}$ Western countries were described as friends and models for learning, whereas communist countries, particularly the PRC, were portrayed as foes and as having inferior political and economic systems.

In the 1990s, Hong Kong and Taiwan authorities began referring to globalization as they discussed long-standing educational problems (such as high examination pressure on students). Globalization was invoked as a justification to reform the education systems and curricula. ${ }^{26}$ A survey about values education in Hong Kong and Taiwan found that elite respondents did not rank global awareness as an important theme in school. ${ }^{27}$ However, in both places reforms generated an awareness of the need to emphasize and

${ }^{23}$ Curriculum Development Council, Guide to the Primary Curriculum (Hong Kong: Government Printer, 1993), Guide to the Secondary 1 to 5 Curriculum (Hong Kong: Government Printer, 1993), and Guide to the Sixth Form Curriculum (Hong Kong: Government Printer, 1993).

${ }^{24}$ Ministry of Education, Guomin Xiaoxue Kecheng Biaozhun (Curriculum standards of elementary schools) (Taipei: Ministry of Education, 1993), and Guomin Zhongxue Kecheng Biaozhun (Curriculum standards of junior high schools) (Taipei: Ministry of Education, 1994).

${ }^{25}$ National Institute for Compilation and Translation, Gongmin (Civics), vols. 2-3 (Taipei: National Institute for Compilation and Translation, 1999).

${ }^{26}$ Curriculum Development Council, Learning to Learn (Hong Kong: Printing Department, 2001); Ministry of Education, Guomin Zhongxiaoxue Jiunian Yiguan Kecheng Zanxing Gangyao (Nine-year comprehensive curriculum for elementary and junior high education) (Taipei: Ministry of Education, 2000).

${ }^{27}$ Hsin Ming Samuel Huang, "Taiwan: Toward a Responsive Society," pp. 145-72; Wing On Lee, "Hong Kong: The Quality of Self in Citizenship," pp. 207-26, both in Values Education for Dynamic Societies: Individualism or Collectivism, ed. William K. Cummings, Maria Teresa Tatto, and John Hawkins (Hong Kong: University of Hong Kong Comparative Education Research Centre, 2001). 
broaden the global dimensions of citizenship to include students' relations to the global economy and their social entitlements and responsibilities in global society. The authorities responded to these perceived needs by intensifying the delivery of transnational skills of English language and information technology. ${ }^{28}$

In Hong Kong, global citizenship began to be taught as a component of civic education in the first 3 years of secondary school, starting in 1998. Throughout the curriculum, 20 (out of 150) lessons are designed to help students think more globally. Their aim is to let children appreciate the heritage of human civilizations and the world's diversity. Lessons also relate global citizenship to individuals' duties and responsibilities. Ultimately their goal is to give students the tools to analyze the problems, causes, and solutions associated with such issues as global ecology, world peace, and fair distribution of resources. ${ }^{29}$ As a result of recent curricular reform, primary and senior secondary curricula also focus on issues of global citizenship in Hong Kong. The objective is to promote active responsibility and produce citizens of the world (as well as of Hong Kong and of China). ${ }^{30}$ The curriculum seeks to impart over 70 values and attitudes, such as the sanctity of life, human dignity, rationality, self-determination, openness, equality, plurality, interdependence, sustainability, human rights, and respect for the rule of law. One overarching goal is to help students develop perspectives for making judgments on world issues. $^{31}$

Taiwan's government expresses similar concerns for promoting global citizenship in its educational reforms. In its final report, Taiwan's Commission on Education Reform recommended fostering students' consciousness of the international community with different cultures and traditions as one of six goals for achieving a modernized educational system. ${ }^{32}$ This goal later became one of 10 goals that have been implemented gradually by the new compulsory education curriculum since 2001-2. ${ }^{33}$ Students are expected to develop a basic understanding and respect for different peoples and cultures, to learn and appreciate their own and others' histories, to develop awareness of the world as an integral "global village" (deqiucun), and to learn social interdependence, mutual trust, and cooperation.

\footnotetext{
${ }^{28}$ Education and Manpower Bureau, Information Technology for Learning in a New Era: Five-Year Strategy, 1998/99 to 2002/03 (Hong Kong: Printing Department, 1998); Ministry of Education, Zixun Jiaoyu Jichu Jianshe Jihua (The plan for the construction of the basic infrastructure for education in information technology, 1997-2001) (Taipei: Ministry of Education, 1996).

${ }^{29}$ Curriculum Development Council, Civic Education: Secondary 1-3 (Hong Kong: Printing Department, 1998).

${ }^{30}$ Curriculum Development Council, Learning to Learn.

${ }^{31}$ Curriculum Development Council, Learning to Learn: Key Learning Area, Personal, Social and Humanities Education (Consultation Document) (Hong Kong: Printing Department, 2000).

${ }^{32}$ Executive Yuan Commission on Education Reform, Jiaoyu Gaige Zhongziyi Baogaoshu (Final report on consultation for education reform) (Taipei: Executive Yuan Commission on Education Reform, 1996).

${ }^{33}$ Ministry of Education, Guomin Zhongxiaoxue Jiunian Yiguan Kecheng Zanxing Gangyao.
} 
Similar to the personal, social, and humanities education area in Hong Kong, social studies in Taiwan is designed to promote students' global awareness. This learning area covers past and contemporary relations of China with Asia and the rest of the world, and ends with the interconnectivity of the globe as the final spatial-temporal axis to which all of the other (eight) axes of human activities in Taiwan are linked. Students, particularly at upper primary and junior secondary levels, are expected to know how the Taiwanese people are connected and affected by such global networks as transportation and information. They are also expected to become aware of international concerns, conflicts, problems, and issues. Children are taught to respect people of different cultures and the need for ecological protection.

From Delocalization to Localization in Citizenship Education

Since the 1990s, parallel to the incorporation of global dimensions and in response to democratization and changes in their relations with the Chinese mainland, the Hong Kong and Taiwan governments have reinstated an emphasis on local identities. This was seen specifically in language and local citizenship education. These reforms ran counter to actions taken during the 1980s, when local concerns and identities were suppressed in each society.

Prior to 1980, Hong Kong and Taiwan each sought to delocalize their school curricula by suppressing people's primary concerns and their local political collective identities. They did so using different strategies and for different reasons: colonization in Hong Kong and the resumption of power after decolonization in Taiwan. Hong Kong was a British colony between the 1840s and 1997. Hong Kong's secondary school curriculum named two history subjects-Chinese history and history. ${ }^{34}$ The former covered about 4,000 years of China's recorded past up to the history of the PRC before 1976, and the latter focused mainly on European historical events, political systems, and cultural traditions.

Despite the resumption of sovereignty from Japan, which had ruled Taiwan for 5 decades (1895-1945), the KMT in Taiwan, like the colonial government of Hong Kong, suppressed local concerns. This suppression can be seen as a strategy that the KMT used to facilitate and consolidate its power in Taiwan after moving its seat from the Chinese mainland. Mandarin, the major, public oral language of the mainlanders (about 15 percent of the population) who had moved with the KMT to Taiwan was (and is) the official language. Two major local dialects (Southern Fujianese and Hakka) and about 10 aboriginal languages of native Taiwanese (together about 85 percent of the population) were banned in classrooms where speaking them could

\footnotetext{
${ }^{34}$ Flora Kan and Edward Vickers, "One Hong Kong, Two Histories: 'History' and 'Chinese History' in the Hong Kong School Curriculum,” Comparative Education 38 (2002): 73-89.
} 
lead to punishment. ${ }^{35}$ Teaching the history and development of pre-1949 Taiwan was also forbidden, and geography and history focused on the Chinese mainland. As a result, except for Southern Fujianese, local and aboriginal languages began to fade-aboriginal languages the fastest, followed by Hakka. ${ }^{36}$

The policy of delocalization in Hong Kong and Taiwan kept students from fostering their local identities, learning about local history and political developments, and reflecting on how they were ruled and administered. In particular, the mass media featured complaints that many young people in Hong Kong lacked interest in local affairs, although they had a strong sense of being "Hongkongese." ${ }^{37}$ In Taiwan, many students had less knowledge about the cities of Taiwan than did children living on the Chinese mainland. ${ }^{38}$

\section{Localism in the Hong Kong Curriculum in the 1990s}

In the 1990s, curricular reforms in Hong Kong and Taiwan helped consolidate the status of local elements that previously had been undermined or suppressed. In the 1980s, the colonial government of Hong Kong gradually realized the importance of promoting participation in community affairs and cultivating a sense of belonging to Hong Kong. Three factors contributed to this realization. First, the social unrest of the 1960s challenged social stability, as well as the colonial administration's legitimacy and authority. Second, limited democratization played a role. The gradual opening up of the political system allowed people to participate in local affairs by electing representatives to district boards in the early 1980s and later to the Legislative Council, although of course they could not elect the governor. The third factor was the signing of the Sino-British joint declaration in 1984, which established the peaceful transfer of Hong Kong from the United Kingdom to the PRC in 1997. This led to a change in the Hong Kong people's collective political identity, as they moved from a self-perception of colonial subjects to citizens of the Hong Kong Special Administrative Region (SAR) in the PRC. In his first policy speech as chief executive of the SAR, Tung Chee-Hwa encouraged his fellow citizens to be "masters" of Hong Kong. ${ }^{39}$ Since this time, schools

\footnotetext{
${ }^{35}$ Yong Sheng Ou, "Xaingtu Jiaoyu De Linian Yu Sheji" (The concept and design of homeland studies), in Xiangtu Jiaoyu (Homeland education), ed. Zheng Jie Huang and Long Sheng Li (Taipei: Han Uen Bookstore, 1995), pp. 10-23.

${ }^{36}$ Feng Fu Tsao, "The Language Planning Situation in Taiwan," in Language Planning in Nepal, Taiwan and Sweden, ed. Richard B. Baldauf, Jr., and Robert B. Kaplan (Clevedon, England: Multilingual Matters, 2000), pp. 60-106.

${ }^{37}$ Joseph Y. S. Cheng, "Values and Attitudes of the Hong Kong Community," in Hong Kong Trends, 1989-1992, ed. Paul Chun Kuen Kwong (Hong Kong: Chinese University Press, 1992), pp. 17-46.

${ }^{38}$ Yun Lim Deng, Kaifang Jiaoyu Yu Jiaoyu Gaige (The opening up of education and education reform) (Kaohsiung: Kaohsiung Fuwen, 1997).

${ }^{39}$ Hong Kong Government, The 1997 Policy Address: Building Hong Kong for a New Era (Hong Kong: Printing Department, 1997).
} 
have been under strong pressure to prepare students for dual citizenship, both in the SAR of Hong Kong and in the PRC. ${ }^{40}$

In response to this pressure, the Hong Kong government subsequently introduced three measures to develop people's citizenship knowledge, skills, and sense of belonging. First, it introduced civic education. As long ago as 1975, the government introduced social studies as a subject for junior secondary students to help foster their sense of belonging to Hong Kong. Later, more topics on the structure of government, policy-making processes, political elections, and local affairs were incorporated into the subject of "economic and public affairs." Notwithstanding these precedents, the focus widened following the Sino-British declaration. Hong Kong's government encouraged schools to promote civic education and, in an unprecedented manner, the Guidelines on Civic Education in Schools emphasized political knowledge and skills, a critical awareness of local affairs, and an appreciation of Hong Kong's cultural heritage and ways of life. ${ }^{41}$

Another measure incorporated local history into the two history subjects in secondary schools. An independent topic, Hong Kong history, was inserted into the curriculum in 1998-99. This new, local component covers different developmental phases of Hong Kong, ranging from traditional rural life centuries ago to modern life in the twentieth century. ${ }^{42}$ On average, this component constitutes about one-fifth of the junior history curriculum. In 1997, a very light version of local history was introduced into the Chinese history curriculum for junior secondary students: teachers could mention Hong Kong whenever pre-1976 China was being discussed..$^{43}$

The third measure of 1997 intensified the use of the major local dialect, Cantonese, as the oral medium of instruction in secondary schools, although there are other local dialects, such as Fujianese. As a British colony, Hong Kong had been caught in the dilemma of whether to use Chinese or English as the medium of instruction in secondary schools, although Chinese was (and is) used principally in most primary schools. Most secondary schools claimed to use English as the medium of instruction, but many practiced

\footnotetext{
${ }^{40}$ Paul Morris, "Preparing Pupils as Citizens of the Special Administrative Region: Curriculum Change and Control during the Transition Period," in his Curriculum Development in Hong Kong, 2d ed. (Hong Kong: University of Hong Kong, Faculty of Education, 1995), pp. 118-41.

${ }^{41}$ Education Department Curriculum Development Committee, Guidelines on Civic Education in Schools (Hong Kong: Government Printer, 1985). These guidelines were criticized for overemphasizing social stability and responsibility, and for depoliticizing civic education; see Wing On Lee, "Controversies of Civic Education in Political Transition: Hong Kong," in Civic Education across Countries: Twenty-Four National Case Studies from the IEA Civic Education Project, ed. Judith Torney-Purta, John Schwille, and Jo-Ann Amadeo (Amsterdam: IEA, 1999), pp. 313-40; Sai Wing Leung, "Depoliticization and Trivialization of Civic Education in Secondary Schools: Institutional Constraints on Promoting Civic Education in Transitional Hong Kong," in Quality in Education: Insights from Different Perspectives, ed. Ping Kee Siu and Tim Kui Tam (Hong Kong: Educational Research Association, 1995), pp. 283-312. 1996).

${ }^{42}$ Curriculum Development Council, History (Secondary 1-3) (Hong Kong: Printing Department,

${ }^{43}$ Curriculum Development Council, Zhongguo Lishi (Secondary 1-3) (Chinese history) (Hong Kong: Printing Department, 1997).
} 
mixed-code teaching, by relying on Cantonese with some English terminology, along with English textbooks and examinations. ${ }^{44}$ After issuing an unprecedented guideline on the medium of instruction, ${ }^{45}$ the Education Department forced 223 local public secondary schools to change gradually to Chinese, starting with their secondary 1 level (equivalent to seventh grade), while it allowed 114 schools to continue using English. This suddenly increased the number of secondary schools using Chinese as their medium of instruction from 70 to about 300. Meanwhile, the percentage of teaching periods using Chinese as the medium of instruction in nonlanguage subjects at the senior secondary level increased from 33 percent in 1998-99 to 56 percent in $2001-2 .^{46}$

"Nativist" Education in Taiwan in the 1990s

As in Hong Kong, a significant sociopolitical shift in Taiwan's curriculum has begun to emphasize local cultures and identities, though in the latter case the shift was away from "mainlandization." This shift was started by civil society groups, schools, and the government, under the KMT's leadership in the early 1990s and reinforced by the new government under the Democratic Progressive Party (DPP) starting in 2000. ${ }^{47}$ In the late 1980s, some local groups used the momentum of democratization to press for preserving local cultures and identities by incorporating "nativist" education (xiangtu jiaoyu)-the learning of local dialects, history, arts, cultures, and contemporary developments-into the formal curriculum. In response, some schools piloted "nativist" education in the form of optional, extracurricular activities. Without major support from local governments, teachers independently developed their own teaching materials by collecting information on the geography, history, religions, arts, and famous people of their locale. In an effort to gain support from ethnic groups in local political elections, in the early 1990s the local governments of Ilan, Pingtung, and Taipei counties began promoting this kind of "nativist" education in the schools under their jurisdiction. Ilan County was the first to start teaching Southern Fujianese in primary and junior secondary schools, stipulating that students no longer should be discouraged or punished for speaking dialects in school. ${ }^{48}$

Under pressure from social groups and political parties, schools, and local

\footnotetext{
${ }^{44}$ Robert Keith Johnson, "Language and Education in Hong Kong," in Language in Hong Kong at Century's End, ed. Martha C. Pennington (Hong Kong: Hong Kong University Press, 1998), pp. 265-81.

${ }^{45}$ Education Department, Medium of Instruction: Guidance for Secondary Schools (Hong Kong: Education Department, 1997).

${ }^{46}$ Education Department, "Study on Enrichment of Language Learning Environment" (paper presented to the Legislative Council Panel on Education, Hong Kong, April 23, 2001).

${ }^{47}$ Wing-Wah Law, "Education Reform in Taiwan: A Search for 'National' Identity through Democratisation and Taiwanisation," Compare 32 (2002): 61-81.

${ }^{48}$ Government Information Office, 2001 Republic of China Yearbook (Taipei: Government Information Office, 2001).
} 
governments in the mid-1990s, the central government under the KMT began to address the preservation of local identities and "nativist" education. Special attention was paid to ethnic groups, representing 400,000 people of different aboriginal groups and 4 million Hakka people, whose languages and cultures had been marginalized or were at the point of disappearance. In 1998, a law was enacted to protect the rights of indigenous peoples to learn their native languages, history, and cultures in school. In particular, Taiwan established the Council of Aboriginal Affairs in 1996 and the Council for Hakka Affairs in 2001 in order to preserve this cultural heritage.

The preservation of local cultures and identities has been consolidated in the new 9-year compulsory curriculum, which both the KMT and DPP have developed and gradually introduced into primary and junior secondary levels since 2002. Fostering "nativist" consciousness (together with global awareness) is one of the curriculum's five emphases. The theme of homeland transcends the seven key learning areas (language; life; health and physical education; social studies; arts and humanities; nature, science, and technology; and mathematics), and different areas of "nativist" concern are distributed across the four levels of the school system.

In 2001, the Ministry of Education offered training to over 1,200 teachers of local languages and allowed them to teach using local dialects. Now primary students from primary 1 to primary 6 are being introduced to one of the three native languages (xiangtu yuyan)-Southern Fujianese, Hakka, and any one aboriginal language. These native languages are taught at least once a week, and they amount to 20-30 percent of lessons for the language key learning area. Junior secondary students can choose one local language as an elective.

\section{Redefining the National Dimension of Citizenship Education}

Besides cultivating local identity and citizenship, Hong Kong and Taiwan have redefined the curriculum's sociopolitical components related to national identity, but in different directions. Hong Kong attempted to render the school curriculum more Chinese by adopting the national identity of the PRC, whereas Taiwan tried to create its own national identity, distancing itself from the mainland and advocating Taiwan as a de facto independent political entity.

Before the early 1980s, Hong Kong's colonial administration depoliticized education and distanced its students from the Chinese mainland. It stipulated that no political symbols, salutes, songs, or activities were to be allowed in schools. ${ }^{49}$ Cultural subjects, such as music, were no exception. ${ }^{50}$ Even teachers

\footnotetext{
${ }^{49}$ Hong Kong Government, Education Regulations: Subsidiary Legislation, Chapter 279, and Education Regulations: Subsidiary Legislation, Chapter 279 (Amended) (Hong Kong: Government Printer, 1991).

${ }^{50}$ Wai Chung Ho, "The Socio-Political Transformations and Hong Kong Secondary Music Edu-
} 
of civic education rarely talked in class about politics, of which they had no professional knowledge. ${ }^{51}$ The PRC's national anthem and flag were forbidden in school. Furthermore, students were not taught about contemporary developments in the Chinese mainland.

The depoliticization, delocalization, and deaffiliation from the Chinese mainland in Hong Kong education can be seen in itself as a unique form of politicization. Despite creating a sociopolitical environment for economic development and education, the cost of this negative politicization was immense. Lacking a clear political and cultural identity, many Hong Kong ethnic Chinese referred to themselves as Chinese or as Honkongese. They were criticized by many local scholars and the mass media for lacking identification with either the United Kingdom or the PRC, being alienated from the political arena, being unable to discuss government policies and political affairs or to exercise their civil rights, and being weak in civic knowledge and showing less interest and concern for China than local affairs. ${ }^{52}$

The government of Hong Kong SAR politicizes the school curriculum by enhancing the public's understanding of the PRC and Chinese culture and strengthening their sense of belonging and commitment to the country. Four measures have been introduced to help students develop their sense of a new national identity within the PRC. Geographically, the Chinese mainland, which had been considered a forbidden zone, is highlighted as an important place for students' and teachers' exchange activities. Many Hong Kong schools organize study visits to the mainland to expose students to Chinese cultures and mainland schools and to provide teachers with staff development. The Hong Kong government has subsidized the training of primary and secondary school principals in teacher education institutes in Beijing and Shanghai. Different central and regional government agencies also invite Hong Kong academics, school teachers, and students to visit various institutions and schools and to attend different ceremonies, such as the 1999 celebration of the fiftieth anniversary of the national founding in Beijing.

Culturally, the school curriculum emphasizes Chinese elements, including language, art, religion, and academic work. The curriculum also covers Chinese values and beliefs, as well as the geography and history of contemporary China. A government survey shows that these six Chinese elements have

cation: Politicization, Culturalization and Marketization," Bulletin of the Council for Research in Music Education (1999): 41-56.

${ }^{51}$ Sai Wing Leung (n. 41 above).

${ }^{52}$ Mark Bray, "Colonialism, Scale, and Politics: Divergence and Convergence of Educational Development in Hong Kong and Macau," Comparative Education Review 36 (1992): 322-41. Kwan Choi Tse, "Preparing Students for Citizenship? Political Education in Hong Kong," Education and Society 16 (1998): 5-15. See also the documents of the Curriculum Development Council, A Study on the Development of Civil Awareness and Attitudes of Pupils of Secondary Schools in Hong Kong (Hong Kong: Curriculum Development Council, 1992), and A Study on the Development of Civil Awareness and Attitudes of Pupils of Primary Schools in Hong Kong (Hong Kong: Curriculum Development Council, 1994). 
permeated, to different degrees, over 100 syllabi of over 40 school subjects. ${ }^{53}$ Chinese history and culture are specifically designated as "core elements of learning" in the personal, social, and humanities education key learning area. ${ }^{54}$ Extracurricular activities related to Chinese culture also have been developed or intensified, such as Chinese orchestras and bands, Chinese dance clubs, and kung fu (Chinese martial arts) classes.

Regarding language, Putonghua (a standardized variety of Mandarin adopted by the PRC as the national oral language) is now offered as a school subject. The Hong Kong government has not adopted Putonghua as the medium of instruction in schools, as is the case for the rest of the PRC, although since the early 1990s it has gained wider acceptance as a school subject for both economic and sociopolitical reasons. ${ }^{55}$ Putonghua became a core subject starting in 1998-99 and a public examination subject in 2000. The number of primary and secondary schools using Putonghua, instead of Cantonese, to teach Chinese language increased from 12 in 1998 to over 40 in 2000. By 2002, several schools also were using Putonghua as the medium of instruction.

Politically, national symbols and rituals have been introduced into schools as signs of sovereignty. To arouse students' respect for the PRC flag, government schools are required and government-aided schools strongly encouraged to fly the flag on important occasions, such as National Day (October 1), Handover Day (July 1), the first day of the school year, and at graduation ceremonies. ${ }^{56}$ The PRC's national anthem is taught in music classes and sometimes played or sung at important school occasions.

Moreover, the triangular relations between Hong Kong, the PRC, and Taiwan in the school curriculum have been revised. Immediately after the handover, the new Hong Kong administration "encouraged" textbooks to be revised in accordance with the principle of "one country, two systems." ${ }^{57} \mathrm{~A}$ comparison of Chinese history textbooks from the same publishers before and after the 1997 handover suggests that, despite the freedom of writing and publication, textbook publishers and writers have followed the administration's guidelines closely. ${ }^{58}$ As a result, China is no longer presented as

\footnotetext{
${ }^{53}$ Curriculum Development Institute, Xuexiao Kechengnei De Zhongguo Yuansu (A report on the Chinese elements in the school curriculum) (Hong Kong: Printing Department, 1998).

${ }^{54}$ Curriculum Development Council, Learning to Learn (n. 26 above).

${ }^{55}$ Bob Adamson and Winnie Lai-Auyeung, "Language and the Curriculum in Hong Kong: Dilemmas of Triglossia," Comparative Education 33 (1997): 233-46.

${ }^{56}$ Education Department, "Shenggua Quoqi Quqi" (Display of the national flag and regional flag), Schools Miscellaneous Circular no. 2/98 (May 27, 1998) and Circular Memorandum CM294/2001 (September 25, 2001).

${ }^{57}$ Curriculum Development Council Textbook Review Committee, Xiuding Keben De Jiben Yuanze (Fundamental principles for revising textbooks) (Hong Kong: Curriculum Development Council, 1998).

${ }^{58}$ For example, Xiao Bing Yip, Guang Yan Yu, and Ai Fang Yu, Hudong Zhongguo Lishi (Interactive Chinese history) (Hong Kong: Manhattan Press, 2000); Guang Yan Yu, Yi Ming Liang, and Wei Ming Chen, Zhongguo Lishi (Chinese history) (Hong Kong: Manhattan Press, 1994).
} 
the northern neighbor but as a nation-state with sovereignty over Hong Kong. To avoid political incorrectness, some textbooks scale down or even delete the section on Taiwan. In those that keep the Taiwan section, it is no longer called the Republic of China, but it is referred to as an integral part of China. The post-1949 Taiwan government is now called the Taiwan Authority, and its president is referred to as its "leader" (a change that also has occurred in television news broadcasts). Textbooks also now report the PRC's intent to incorporate Taiwan under "the principle of one China."

\section{Chinese Identity Tendencies in Taiwanese Education}

Unlike the colonial administration in Hong Kong, the KMT politicized education in Taiwan, making it more China-centered. The goal was to maintain strong historical ties to the Chinese mainland as the rationale for recovering China from the Communist Party. Mandarin was, and still is, Taiwan's only official language. As part of its formal citizenship education, Taiwan students were required to take compulsory political and ideological courses centering on the state's central value system-the Three Principles of the People (nationalism, democracy, and people's social well-being). These were prescribed by Sun Yat-Sen, the founder of the pre-1949 Republic of China on the mainland and transplanted to Taiwan by his successor, Chiang KaiShek, when he retreated to Taiwan in 1949. Some of the KMT's prescribed political symbols, slogans, and messages were deliberately transmitted to students of all levels through standardized curricula; textbooks; extracurricular activities; statues and photos of leaders, as well as other political decorations in the school or classroom; and even in the names of schools or colleges. ${ }^{59}$ The governing ideology behind all of these symbols and discourses centered on familiar political themes: resistance against communism, the inalienable relation of the Taiwan people to the Chinese mainland, Taiwan as the bastion from which to recover the mainland from the Chinese communists, the exaltation of KMT leaders such as Sun Yat-Sen and Chiang Kai-Shek, and the derogation of Chinese communists as bandits.

Unlike leaders in Hong Kong, those in positions of authority in Taiwan today want to develop a national identity separate from the Chinese mainland. In the 1990s, Taiwan began to repoliticize the school curriculum by playing down the Chinese mainland and emphasizing Taiwan as a political entity. In social studies, students from primary 4 to junior secondary 3 are now required to learn about Taiwan's geography, the history of pre-1945 Taiwan under different external powers, Taiwan's social and political developments since 1945, and Taiwan's relations with the Chinese mainland, Asia, and the rest

\footnotetext{
${ }^{59}$ Ching Tien Tsai, "Chineseization and the Nationalistic Curriculum Reform in Taiwan," Journal of Education Policy 17 (2002): 229-43.
} 
of the world.$^{60}$ In comparison, there are only two units addressing the Chinese mainland: the geography and history of China for junior secondary levels $1-3$, in which there is only a small section on the Chinese civil war between the KMT and the communists that ended in 1949.

More important and more controversial, Taiwan's new school curriculum repositions its political relation to the mainland. The idea of Taiwan as an independent political entity that had never been ruled by the PRC was featured in the course, "Introduction to Taiwan," which was incorporated into the curriculum at the junior secondary level in 1997. Analysis of the official textbooks for this subject reveals that they had already incorporated five major changes to the former KMT-led government's position on Taiwan's relation to the mainland. ${ }^{61}$

First, what was said to be the geopolitical territory of the Republic of China no longer included the mainland. Second, the "Republic of China" had been extended to the "Republic of China on Taiwan." Third, the "new Taiwan" was assumed to be the Taiwanese people's ultimate homeland, rather than a periphery of the Republic of China and the bastion for recovering the mainland. Fourth, the Taiwanese people were seen as one "community sharing the same life" (shengming gongtongti) or one "community sharing the same fate" (mingyun gongtongti), regardless of their or their ancestors' place of origin and time of settlement in Taiwan. Fifth, the Taiwanese were given a dual role as masters of their own past and future (rather than subject to external powers, including the KMT) and as defenders of the "new Taiwan" against any military and political threats from external powers, including the PRC. ${ }^{62}$

As a result of curricular reform, "Introduction to Taiwan" was gradually withdrawn in 2001-2. This withdrawal sparked protest from advocates of Taiwan's independence. In response, the Ministry of Education, under the leadership of the DPP (which similarly advocates independence for Taiwan), claimed that the contents of the subject already informed different key learn-

\footnotetext{
${ }^{60}$ Ministry of Education, Guomin Zhongxiaoxue Jiunian Yiguan Kecheng Zanxing Gangyao: Shehui Xuexi Lingyu (Nine-year comprehensive curriculum for elementary and junior high education: Social studies key learning area) (Taipei: Ministry of Education, 2001).

${ }^{61}$ National Institute for Compilation and Translation, Renshi Taiwan (Introduction to Taiwan), 2d ed., vols. 1-3 (Taipei: National Institute for Compilation and Translation, 1999).

${ }^{62}$ Proponents of unification with the Chinese mainland criticized these textbooks for glorifying Japan's contribution as a colonizer to Taiwan's development, for not mentioning the Taiwanese people's suffering and resistance under the Japanese colonial administration, for overemphasizing the differences between Taiwan's four major ethnic groups, for "de-Sinifying" Taiwan, and for advocating Taiwan's independence from the Chinese mainland; see Zu Ji Tang, "Burong Qingshi Jinchenghui: Dui Guomin Zhongzue Jiaokeshu Renshi Taiwan Fei Zhongguohua Qingxiang De Pipan” (Don't let history vanish: A critique of the de-Chineseization tendency in the textbooks of introduction to Taiwan), in Renshi Taiwan Jiaokeshu Pingshi (Commentary on the textbooks of introduction to Taiwan), ed. Nan Cun Xu (Taipei: Renjian, 1999), pp. 9-30.
} 
ing areas of the new basic education curriculum. ${ }^{63}$ In addition, in 2001, the DPP's development in the struggle for democracy was officially incorporated into the history of Taiwan curriculum.

\section{The Tension of Global and Local Identity in a Multileveled Community}

Fostering local identity, rather than global citizenship, is an immediate and urgent concern in transitional societies such as those of Hong Kong and Taiwan. Yet they are similar in some ways to the previously mentioned cases of Australia, Japan, Singapore, the United Kingdom, and the United States. In all of these societies, citizenship curricula are caught in the tension between global and local identities. However, the tensions experienced in Taiwan and Hong Kong are more complicated than the latter case in regard to issues associated with language and sovereignty.

Language is not only an essential tool of communication but also an important mark of identity ${ }^{64}$ In a multileveled polity, languages embody different, though overlapping, cultures and identities to which different players attach different sociopolitical and economic values. The tensions among local, national, and global languages in education are extensions of the tensions among local, national, and global cultures and identities in the wider context and in the struggle between the politico-cultural and economic tasks of education in a global age.

Economic and cultural globalization reinforces the inequality among languages and the hegemony of English across the globe. People from nonEnglish-speaking societies, such as Hong Kong and Taiwan, have been disadvantaged in global competition compared with their counterparts in English-speaking societies (and those societies where learning and speaking English is more widespread, such as former British colonies in North America, the Caribbean, and Africa). If they are to go global, they need to acquire English proficiency.

Despite its global hegemony, English is still not strong enough in Hong Kong and Taiwan to become part of their citizens' global identity. In particular, despite having been used as an official language during the colonial period, Hong Kongers have never regarded the language as a part of their national identity. In both Chinese societies, this can be explained partly by a split in the functions and implications of national or local languages, on the one hand, and the global media of English, on the other. English is linked to international functions and business. Similar to the case of Japan, in both of the Chinese societies discussed in this article English is promoted as an

\footnotetext{
${ }^{63}$ Ministry of Education, "Renshi Taiwan Kecheng Rongru Gelingyu De Kechengzhong" (The infusion of "introduction to Taiwan" into the curriculums of different key learning areas), press release, October 15, 2001

${ }^{64}$ Joshua A. Fishman, The Sociology of Language: An Interdisciplinary Social Science Approach to Language in Society (Rowley, Mass.: Newbury House Publishers, 1972).
} 
instrument for global competition rather than global identity. English instruction is more concerned with how to use the language properly than with understanding the cultures from which it developed. In contrast, the promotion of local dialects or the national language is associated with fostering local or national identity and preserving culture.

The cases of Hong Kong and Taiwan further reveal the emergence of new tensions resulting from conflicts among different education stakeholders. In Hong Kong, Cantonese is less preferable, although it is widely used and associated with local identity. While the Hong Kong SAR government insists on promoting Cantonese as the oral medium of instruction in most secondary schools, many schools, parents, and students prefer using English due to its economic importance. Moreover, there is growing public pressure to replace the local dialect with the national oral language, Putonghua, as the medium of instruction. Putonghua is seen to be of increasing importance to the Hong Kong people because of increasing economic, political, and cultural exchanges with the PRC. Exchanges on equal footing are not yet possible, however, because most teachers and students lack proficiency in Mandarin.

The language-identity issues in Taiwan are subtler than they are in Hong Kong. In Taiwan, the places of origin and the use of national and native languages for public occasions (and the independence of Taiwan from the PRC) have exacerbated long-standing social conflicts between mainlanders and native Taiwanese. The reinstatement of native languages for public occasions (particularly political elections) has eased, but not settled, the conflict between native languages and the national language. In 2002, the Taiwan Solidarity Union, whose spiritual leader is the former President Lee, proposed making the major local dialect, Southern Fujianese, Taiwan's second official language. However, advocates of unification with the PRC defined this as an act of "de-Sinification," and proponents for an inclusive society identified it as a form of discrimination against other native peoples. In response, the Taiwanese government began drafting legislation to define native languages as equal to Mandarin in daily life and public activities. If passed, this legislation would allow these languages to be used as a medium of classroom instruction. Moreover, many parents do not support the learning of local dialects, particularly aboriginal languages, preferring that their children expend more effort on academic subjects and English in order to enhance their professional careers. ${ }^{65}$

The broader significance of the tensions discussed in this article are clear: instead of withering, as predicted by some globalization theorists, the state,

\footnotetext{
${ }^{65}$ Zhong Beng Bai, "You Shuangyu Jiaoxue Lilun Kan Taiwan Yuanzhumin Muyu Jiaoxue" (Bilingual education for Aborigines in Taiwan: From perspectives of bilingual education), in Taiwan Yuanzhumin Jiaoyu (Education for Aborigines in Taiwan), ed. Quan Hu Hong and Xue Yan Wu (Taiwan: Taiwan Normal University Press, 1999), pp. 111-23; Cecilia Fanchiang, "Mother-Tongue Education Off to Rocky Start," Taiwan Journal (2003), retrieved May 15, 2004, from the World Wide Web, http://publish.gio .gov.tw/FCJ/past/03103171.html.
} 
national sovereignty, national identity, and local identities and cultures remain significant factors for the understanding of both citizenship and, consequently, the demands on citizenship education. These are special concerns for societies in transition, such as Hong Kong and Taiwan, as they restructure their curricula's sociopolitical components in response to economic and politico-cultural changes in a global age. Unlike the revival of national identities in citizenship education in Australia, Japan, Singapore, the United Kingdom, and the United States, the emphasis on the national dimension of citizenship education in Hong Kong and Taiwan relates to a change of national identities that resulted from readjusting their political relation to the PRC. However, both Hong Kong and Taiwan have difficulty promoting their new national identities in education, reflecting the complex nature of national identity and the tangled sociopolitical preferences of citizens and the state during a time of social transition.

Since becoming a Special Administrative Region of the PRC in 1997, the Hong Kong people could choose both local Hong Kong and national (PRC) identities. There is evidence that they, by increasingly accepting this dual identity in schools, are placing more emphasis on education for national citizenship. ${ }^{66}$ However, it is common for schools to fly the national flag on Handover Day and National Day, when students and teachers are on vacation, while rarely flying it on other suggested occasions, such as the first day of school and at graduation ceremonies, when students and teachers are present. Additionally, in many schools, the PRC national anthem is not sung in public.

Language may be a barrier to cultivating national identity in Hong Kong because most teachers and students do not have sufficient proficiency in Putonghua to sing the PRG's national anthem. Another possible reason is the overseas citizenship of many Hong Kong professionals. Before Hong Kong's transition to a Special Administrative Region of the PRC, many school principals and teachers obtained passports from other countries (e.g., Australia, Canada, Singapore, the United Kingdom, and the United States) as a potential safety net. As a result, they now have a split allegiance to their countries of naturalization and to the PRC, particularly in regards to observing the national flag-raising ceremony and singing the national anthem. Unless such rituals are compulsory, many will choose not to participate, taking instead the observer's role.

Unlike Hong Kong, Taiwan is still searching for its national identity. This cannot be accomplished within its multileveled polity, for Taiwan is a state

\footnotetext{
${ }^{66}$ Breakthrough, Qingshaonian Wenhua Gazhi Yanjiu (A study on values of youngsters) (Hong Kong: Breakthrough, 2001); Hong Kong Federation of Youth Groups, Youth Trends in Hong Kong 2001 (Hong Kong: Hong Kong Federation of Youth Groups, 2002); Hong Kong Federation of Education Workers, Xianggang Zhongxiaoxue Guomin Jiaoyu Wenjuan Diaozha Jieguo (A report on the survey of national citizenship education in primary and secondary schools in Hong Kong) (Hong Kong: Hong Kong Federation of Education Workers, 2003).
} 
without sovereignty and with no national identity recognized by the international community. The Taiwanese government has attempted to give up its old national identity (affiliated with the pre-1949 Republic of China, including both Taiwan and the Chinese mainland) and to upgrade its subnational identity (Taiwan as part of China) to the national level (Taiwan as a nation-state). Attempts to create a new national identity and introduce a tripartite framework for citizenship education have created more problems than solutions for its people, including teachers and students.

Since it lost membership in the United Nations (to the PRC) in 1971, Taiwan has faced serious setbacks in gaining recognition of its "nationhood" from the international community. Thus, it has been denied official membership and rights of representation as well as participation in international organizations, including UNESCO and the World Health Organization, despite applying for such annually since the early 1990s. Also, the PRC has refused to denounce the use of military force to settle the issue of unification with Taiwan. However, Taiwan's government, under the KMT before 2000 and the DPP thereafter, has reiterated repeatedly that Taiwan and the PRC are two independent and equal-standing political entities, and it has deliberately delayed negotiating with the PRC. The Taiwan government also launched a movement to correct the country's name: the word "China" has been replaced by "Taipei" in government-sponsored newspapers and journals, and the word "Taiwan" has been added to passports. Absent the unlikely concession by the PRC, however, Taiwanese efforts to promote national sovereignty in schools and society are just as unrealistic as their efforts to recover the Chinese mainland from the Chinese Communist Party.

\section{Conclusions}

Taiwan and Hong Kong share a common cultural heritage and confront similar challenges associated with economic globalization. They also exemplify contrasting responses to those that would be expected by proponents of globalization who emphasize convergence and the denationalization of citizenship. By contrast with proponents of convergence, the two cases reported here support those who advocate an accommodative framework, one allowing for an interplay among global, regional, and local forces leading to both homogeneity and heterogeneity. For both societies, geopolitical boundaries and collective political identities in the multileveled community are equally important to their competition for capital in the borderless, global market. Both states play a proactive, leading role in redefining local and national citizenships, shaping the content of citizenship education and balancing the local, national, and global components of their respective identities. Like many other societies, they have introduced a tripartite framework for citizenship, including local, national, and global dimensions. Their curricular responses embody the widespread tension between global and local 
identities. At the same time, in both Hong Kong and Taiwan, unlike other societies mentioned in this article, revising school curricula has required a complex reselection rather than mere reassertion or revival of material related to languages and identities. Moreover, the tension in Hong Kong and Taiwan is not simply bipolar (i.e., global-national/local). Rather, it is tripolar, reflecting the complicated interactions among global, national, and local components. Domestic democratic mobilization and a shifting relation to the Chinese mainland in Hong Kong and Taiwan have led authorities to focus curricula on promoting local and national identities, with less emphasis on global citizenship. These issues have determined politicians' agendas and are seen as increasingly important for the state's effective governance. These concerns for local identity also have made the tensions of Hong Kong and Taiwan different not only from those of other societies but also from each other. For each case, local, national, and global languages carry distinctive sociopolitical and economic values. Neither local nor global identity can supersede-or be superseded by-national identity.

In addition to barriers represented by the state's preferences for supporting local and national citizenship, the promotion of global citizenship is limited by its publicly perceived irrelevance. Global citizenship is only a metaphor, despite the existence of international laws and conventions and increasing global internationalization. There are no commonly shared symbols to arouse people's sense of belonging to the global society that are comparable to those associated with national identity, such as a flag, anthem, or emblem. Unlike local or national citizenship, global citizenship is not a politico-legal entity with which people can directly affiliate and within which they can exercise their rights and face sanctions for failing in their responsibilities. Indeed, for the great majority of the world's population, there are very few opportunities to be world citizens. ${ }^{67}$ The rejection of Taiwan's representation and participation in important international organizations (such as the United Nations and the World Health Organization) further reveals the importance of nationhood as an essential prerequisite of global citizenship. It also demonstrates the inability of a de facto political entity to select its own national identity and the fundamental nature of global polities that operate on the assumption and basis of nation-states. Globalists, who take nationhood for granted but want to denationalize or deterritorialize citizenship, overlook this fact. Nationhood and statehood continue to be significant concerns in citizenship education in the globalizing world.

\footnotetext{
${ }^{67}$ Peter Jarvis, "Globalisation, Citizenship and the Education of Adults in Contemporary Society," in Learning Democracy and Citizenship: International Experiences, ed. Michele Schweisfurth, Lynn Davis, and Clive Harber (Oxford: Symposium Books, 2002), pp. 291-99.
} 
Copyright of Comparative Education Review is the property of Comparative \& International Educational Society and its content may not be copied or emailed to multiple sites or posted to a listserv without the copyright holder's express written permission. However, users may print, download, or email articles for individual use. 